\title{
Pregnancy associated plasma protein-A is necessary for expeditious fracture healing in mice
}

\author{
Bradley S Miller, James T Bronk ${ }^{1}$, Takayuki Nishiyama ${ }^{1}$, Hiroshi Yamagiwa ${ }^{1}$, Alok Srivastava ${ }^{1}$, \\ Mark E Bolander ${ }^{1}$ and Cheryl A Conover \\ Endocrine Research Unit, 'Division of Orthopedic Surgery, Mayo Clinic, 200 First, Street SW, 5-194 Joseph, Rochester, Minnesota 55905, USA \\ (Requests for offprints should be addressed to C A Conover; Email: conover.cheryl@mayo.edu)
}

\begin{abstract}
Pregnancy-associated plasma protein A (PAPP-A), a metalloproteinase that regulates IGF bioavailability in vitro through cleavage of inhibitory IGF-binding protein-4 (IGFBP-4), has been implicated in skeletal development and injury repair responses. However, direct in vivo data are lacking. In this study, we used PAPP-A knock-out (KO) mice to determine the role of PAPP-A in fracture repair. Stabilized mid-shaft fractures were produced in femurs of 3-month-old mice. At 14 days post-fracture, complete bony bridging of the fracture callus was seen radiographically in wild-type but not in PAPP-A KO mice. Histological examination 5 to 28 days post-fracture showed reductions in the amount of intramembranous bone formation, cartilage production, endochondral ossification and remodeling in PAPP-A KO compared with wild-type mice. However, fracture healing appeared similar in both
\end{abstract}

groups at 42 days post-fracture when analyzed by histology. A similar degree of healing strength in wild-type and PAPP-A $\mathrm{KO}$ femurs was demonstrated by mechanical testing at 28 and 42 days post-fracture. Untreated cultures of day 5 fracture calluses from wild-type mice showed robust IGFBP-4 protease activity and IGF receptor phosphorylation, whereas fracture calluses from PAPP-A KO mice had no IGFBP-4 protease activity and reduced IGF receptor phosphorylation. These data demonstrate a marked delay in fracture healing in PAPP-A KO compared with wild-type mice, and suggest that PAPP-A is necessary in the early phases of the process for expeditious fracture repair. The ability of PAPP-A to enhance local IGF action may be an important mechanism for optimizing the fracture repair response.

Journal of Endocrinology (2007) 192, 505-513

\section{Introduction}

Fracture repair is a process involving several cell types undergoing accelerated activity during an immediate inflammatory reaction, intramembranous ossification, chondrogenesis, and endochondral ossification resulting in the formation of a fracture callus followed by bony union and remodeling (Joyce et al. 1990a, Gerstenfeld et al. 2003). Although the sequence in fracture repair is well-established, the regulatory roles played by growth factors, cytokines and proteases in this process are only beginning to be worked out. One of the growth factor systems likely to be important in fracture healing is the insulin-like growth factor (IGF) system (Trippel 1998). Indeed, fracture repair recapitulates the process of new bone formation at the epiphyseal growth plate (Ferguson et al. 1999, Gerstenfeld et al. 2003), and the IGFs were discovered based on their essential role in this new bone formation required for linear growth (Le Roith et al. 2001). IGF-I and IGF-I receptor expression have been shown to have widespread distribution within the callus in most cell types and differentiation stages of the osteoblast lineage, in the newly proliferating and early hypertrophic chondrocytes, and in mesenchymal cells (Andrew et al. 1993, Trippel 1998,
Okazaki et al. 2003, Wildemann et al. 2004). Moreover, IGFs are mitogenic in vitro for cells important in fracture healing, including chondrocytes and osteoblasts, and IGF-I has been shown to stimulate proteoglycan synthesis in growth plate chondrocytes and collagen synthesis in bone (Vetter et al. 1986, McCarthy et al. 1989, Wergedal et al. 1990, Conover \& Rosen 2002).

However, the IGF system itself is complex with not only ligands and specific receptors mediating the anabolic response, but also IGF-binding proteins (IGFBPs) and IGFBP proteases that ultimately determine the response (Rechler \& Clemmons 1998, Bunn \& Fowlkes 2003, Duan \& $\mathrm{Xu}$ 2005). To our knowledge, there are no published data on IGFBPs and fracture repair. However, there are several studies on IGFBPs and basic bone metabolism (reviewed in Conover \& Rosen 2002). All six of the high affinity IGFBPs are secreted by bone cells in vitro, depending on the cell line and culture conditions (Hassager et al. 1992, Conover et al. 1996, Conover \& Rosen 2002). IGFBP-4 is a major IGFBP expressed by bone cells and is a potent inhibitor of IGF action in vitro as well as in vivo (LaTour et al. 1990, Zhang et al. 2003). Of particular note, IGFBP-4 over-expression targeted to osteoblasts sequestered IGF with consequent impairment of 
IGF action in skeletal tissue (Zhang et al. 2003). This inhibitory effect was more effective if the IGFBP-4 was engineered to be protease-resistant (Qin et al. 1999), and is consistent with the data from Miyakoshi et al. (2006) indicating that IGFBP-4 proteolysis is important for the regulation of local IGF bioavailability and bone formation.

The major, if not the only physiological IGFBP-4 protease is pregnancy-associated plasma protein-A (PAPP-A), a metalloproteinase in the metzincin superfamily (Lawrence et al. 1999, Boldt et al. 2001). PAPP-A is expressed by a variety of cells in culture, including osteoblasts, fibroblasts, and vascular smooth muscle cells (Conover et al. 1995, Bayes-Genis et al. 2001, Ortiz et al. 2003) and in periosteal explants (AuwYang et al. 2003). In vitro studies have shown that PAPP-A enhances IGF action through cleavage of IGFBP-4, which markedly diminishes the affinity of IGFBP4 for IGFs (Conover et al. 1995, Byun et al. 2001, Ortiz et al. 2003). PAPP-A is thought to play a similar role in vivo, to increase the availability of free IGF at the local tissue level for enhanced receptor activation during critical periods such as in response to injury. In support of this role, increases in PAPP-A expression have been shown to be associated with healing human skin and neointimal hyperplasia following vascular injury (Bayes-Genis et al. 2001, Chen et al. 2003, Resch et al. 2006). Thus, we hypothesized that PAPP-A was important to optimally promote accelerated activity of IGFs in fracture repair. To test this hypothesis, we compared the process of fracture healing in wild-type and PAPP-A-deficient mice.

\section{Materials and Methods}

\section{Materials}

Tissue culture media and BSA were purchased from Sigma, and IGF-II was from Bachem (Torrance, CA, USA). Protein $G$ Plus/Protein A agarose beads were obtained from Oncogene Research Products (Boston, MA, USA), antiphosphotyrosine antibody (PY20) was from Transduction Laboratories (Lexington, KY, USA), and anti-IGF-I receptor antibody (C-20) was from Santa Cruz, Biotechnology (Santa Cruz, CA, USA). Recombinant IGFBP-4, kindly provided by Dr Claus Oxvig (Aarhus, Denmark), was produced as previously described (Overgaard et al. 2000).

Mice

Mice that carry a targeted mutation in the $P A P P-A$ gene have been characterized previously (Conover et al. 2003).

\section{Fracture model}

This study was approved by the Mayo Clinic Institutional Animal Care and Use Committee. At 100 days of age, wildtype (WT) and PAPP-A knock-out (KO) mice underwent surgery to induce a controlled fracture of the right femur. The mice were anesthetized with ketamine/xylazine and using a parapatellar approach, a 25 gauge needle was inserted into the femoral medullary canal through the knee. The protruding needle and hub was cut at the knee using wire cutters and the end pushed into the bone such that it would not interfere with joint motion. The incision was closed in layers. The right femur of the mouse was then positioned across the stage of the fracture machine such that the blade contacts tissues at the level of the mid-femur (Bonnarens \& Einhorn 1984). The stage was raised until five pounds force was placed on the femur, as measured on the digital display. A $250 \mathrm{~g}$ weight was then dropped $8 \mathrm{~cm}$ to fracture the femur. Radiographs were obtained to evaluate the fracture. The mice received analgesic following the procedure. The mice were sacrificed by lethal injection at intervals following the fracture for analyses, as outlined in Fig. 1. The numbers of mice that were used for each analysis are included in this Figure.

\section{Radiographic evaluation}

Radiographs were taken the day of surgery and 7 and 14 days post-fracture. Min-R2000 Kodak film and the GE AMX4 X-ray unit (General Electric, Milwaukee, WI, USA) were used. Bridging of the fracture callus was assessed by two independent observers.

\section{Histology}

After fixation in 10\% neutral buffered formalin and decalcification, the fractured femurs were processed, paraffin embedded and stained with Hematoxylin and Eosin, Masson's Trichrome and Safranin $\mathrm{O}$ as previously described (Bonnarens \& Einhorn 1984, Joyce et al. 1990b, Jingushi et al. 1992).

\section{IGFBP-4 protease assay}

The fracture callus was dissected from the living anesthetized mouse under sterile conditions and placed in warm serumfree Dulbecco's modified Eagle's medium (DMEM) with

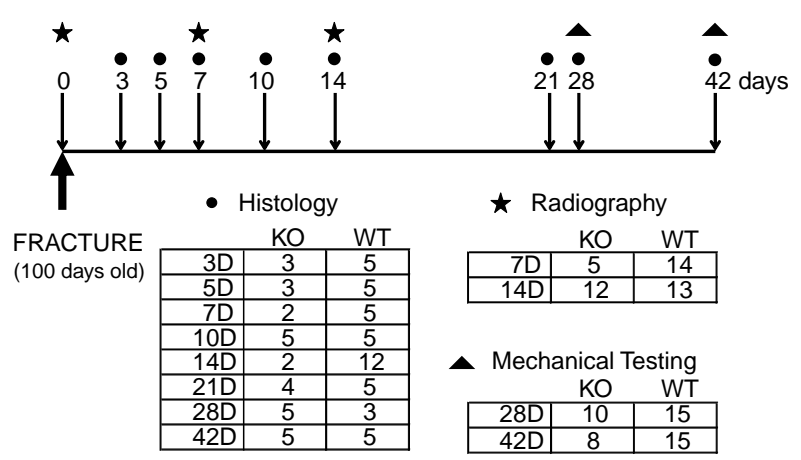

Figure 1 Protocol design for fracture repair. A controlled fracture of the right femur was induced in 100-day-old WT and PAPP-A KO mice. Analyses were performed at the indicated days post-fracture, with the numbers of WT and KO mice shown in the tables. 
$0 \cdot 1 \%$ BSA. Five calluses were transferred to a well of a $24-$ well plate. After $48 \mathrm{~h}$ of incubation at $37^{\circ} \mathrm{C}$, conditioned media were harvested. IGFBP-4 proteolysis was assayed as described previously (Conover et al. 1995, Lawrence et al. 1999, Ortiz et al. 2003), by incubating aliquots of conditioned medium at $37^{\circ} \mathrm{C}$ for $72 \mathrm{~h}$ with radioiodinated recombinant IGFBP-4 in the presence and absence of $5 \mathrm{nM}$ IGF-II. Note: IGF-II binding to IGFBP-4 renders the IGFBP-4 susceptible to cleavage by PAPP-A (Qin et al. 2000). The reaction mixture was resolved by SDS-PAGE and visualized by autoradiography.

\section{Immunoprecipitation and immunoblotting}

The fracture callus was dissected from the living anesthetized mouse under sterile conditions. The callus was quickly washed with ice cold PBS containing phosphatase inhibitors and immediately lysed by mechanical and sonic disruption in lysis buffer containing protease and phosphatase inhibitors. Five fracture calluses were pooled to provide sufficient tissue for analysis. The samples were pre-cleared with Protein G Plus/Protein A-agarose beads and then underwent sequential immunoprecipitation with $4 \mu \mathrm{g}$ control $\mathrm{IgG}$ and $4 \mu \mathrm{g}$ IGF-I receptor antibody followed by incubation with Protein G Plus/Protein A agarose beads. The resulting immunoprecipitates were resolved on SDS-PAGE and immunoblotted with phosphotyrosine antibody (PY20) and anti-IGF-I receptor antibody (C-20), and bands visualized with Enhanced Chemiluminescence products from Amersham Biosciences. Band intensity was quantified by laser densitometry (Ultroscan XL, Pharmacia, Piscataway, NJ, USA).

\section{Mechanical testing}

Mechanical strength testing was performed as previously described (Lotinun et al. 2004). At sacrifice, femurs were frozen at $-20{ }^{\circ} \mathrm{C}$ in normal saline. On the day of strength testing, the bones were removed from the freezer and allowed to thaw to room temperature. The soft tissue was carefully removed from the ends of the bone for embedding. Extra tissue was removed from the callus taking care not to disturb the callus. Diameter of the callus was measured in two planes using calipers and the mean was calculated. The ends of the femurs were embedded in Cerrolow alloy (McMaster Carr) heated to its melting point $\left(47^{\circ} \mathrm{C}\right)$. Special holders were developed to ensure embedding kept the bones in alignment with the axis of the test machine. A uniform length of the middle of the femur including callus is exposed between the embedding blocks. Specimens are kept wet at all times with normal saline. Wood toothpicks were embedded with the femurs to ensure that the bones would not be broken prior to insertion into the test machine. The machine used was custom built for strength testing of small samples (Avalon Technologies, Rochester, MN, USA). After the sample was loaded into the machine and secured, the toothpicks were carefully cut. The samples were tested to failure on tension at
$0 \cdot 4$ degrees per second. Maximum torque (N-mm) was quantified as the maximum force encountered before failure. Ultimate strength $\left(\mathrm{N} / \mathrm{mm}^{2}\right)$ was calculated according to the guidelines put forth by Higdon et al. (1985). Both femurs from each mouse were tested to failure so that the fracture strength data could be normalized to the unfractured femur strength.

\section{Statistical analyses}

Comparisons between WT and PAPP-A KO mice were made using Student's $t$-test, with significance set at $P<0 \cdot 05$.

\section{Results}

\section{Radiology}

Radiology was used to confirm an effective closed fracture on the day of surgery and the progress of healing at days 7 and 14 for WT and PAPP-A KO mice. Radiographs taken after fracture induction indicate a significant delay in healing in the PAPP-A KO mice. At day 7, soft tissue callus formation could be detected in 12 of 14 of the WT but not in any of the PAPP-A KO mice. At 14 days post-fracture, complete bony bridging of the fracture callus was seen in 12 of 13 WT but not in any of the 12 PAPP-A KO mice. However, soft tissue callus was visible in the PAPP-A KO mice at this time, and one of the 12 PAPP-A KO mice showed evidence of calcium bridging.

\section{Histology}

The normal fracture healing process proceeds through the stages of immediate response, intramembranous ossification, chondrogenesis, endochondral ossification and late remodeling (Joyce et al. 1990a, Gerstenfeld et al. 2003). These stages of fracture healing are visible in representative femoral sections collected at intervals following fracture that were stained with Masson's Trichrome to differentiate collagen and bone from smooth muscle in tissues (Fig. 2) and with Safranin $\mathrm{O}$ to monitor cartilage formation (Fig. 3). A summary of the results is presented in Table 1. The immediate response involving the formation of the fracture hematoma was seen at 3 days post-fracture in both WT and PAPP-A KO mice. Intramembranous ossification was demonstrated in WT mice at 5 days by an increase of blue staining bone tissue in the periosteum at the shoulder of the fracture. Only a small amount of intramembranous ossification was seen in PAPP-A KO mice at day 5. Chondrogenesis involves the formation of chondrocytes in the region adjacent to the new bone formed by intramembranous ossification. Chondrocytes are light pink with Masson's Trichrome staining and stain pink-orange with Safranin O. Chondrogenesis began at 5 days post-fracture in WT mice, and was more voluminous in WT than in PAPP-A KO 

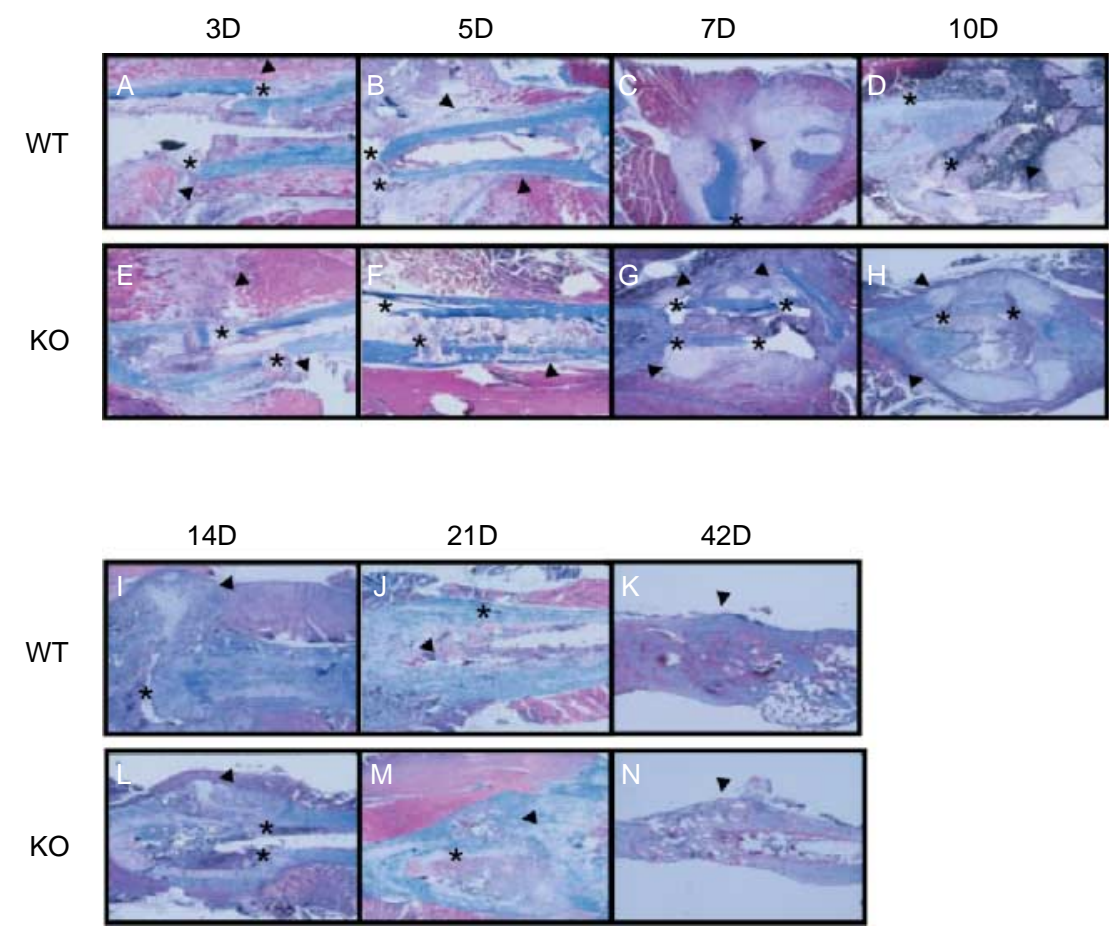

Figure 2 Histology of fractured femurs: Masson's Trichrome. Femoral sections from WT and PAPP-A KO mice were stained with Masson's Trichrome, which is used to differentiate collagen and bone from smooth muscle in tissues. Masson's Trichrome stains the bone blue, blood and smooth muscle red, and cytoplasm of chondrocytes light pink. Asterisks denote the site of fracture. The immediate response involving the formation of the fracture hematoma (arrow head) is seen at 3 days post-fracture in both WT (A) and PAPP-A KO (E).

Intramembranous ossification is demonstrated in WT mice at 5 days (B) by an increase in blue staining bone tissue in the periosteum at the shoulder of the fracture (arrow head).

Chondrogenesis begins at 5 days in WT mice (B) and at 7 days in PAPP-A KO mice (G). It is more voluminous in WT than in PAPP-A KO animals at 7 days (C vs $G$, arrows head), 10 days (D vs $\mathrm{H}$; arrows head), and 14 days (I vs L; arrows head). At 14 days post-fracture, WT mice have nearly completed endochondral ossification of the fracture callus (I; arrow head). However, the PAPP-A KO mice have less bone formation at this point ( $\mathrm{L}$; arrow head). Histological differences in the late remodeling phases at 42 days $(K$ and $N)$ were not remarkable.

animals at 7, 10 and 14 days. Chondrogenesis was not seen in PAPP-A KO mice until day 7. Endochondral ossification involves the differentiation of the cartilaginous callus into bone and is manifest by an increase in the blue staining bone and a reduction in cartilage. At 14 days post-fracture, WT animals have nearly completed endochondral ossification of the fracture callus. However, the PAPP-A KO animals have little bone formation at this time, supporting the radiographic findings. At day 21, the PAPP-A KO animals showed persistent bony bridging with a delay in remodeling. The remodeling delay in PAPP-A KO animals persisted at day 28. There were no major histological differences seen in the late remodeling phase at day 42 post-fracture. Thus, histological examination of fractured femurs demonstrates a delay in chondrogenesis and endochondral ossification in PAPP-A KO mice but with apparently normal histology at completion of the fracture healing process.

\section{Mechanical testing}

Mechanical strength testing of the fractured femur and contralateral femur was performed at 28 and 42 days postfracture (Table 2). The force to failure, a measure of the structural strength of the entire bone, was significantly reduced in fractured femurs from PAPP-A KO compared with WT mice at both time points. The femoral diameter measured at the site of fracture was also significantly reduced in PAPP-A KO mice at both time points. However, the ultimate strength, a measure of the component strength of the bones that corrects for differing diameters, was not different between the WT and PAPP-A KO mice. These results suggest that the bone quality resulting from the fracture healing and post-fracture remodeling process is similar in WT and PAPPA KO mice. When comparing the unfractured and fractured femurs, there were no significant differences between the degree of healing between WT and PAPP-A KO mice. Both 


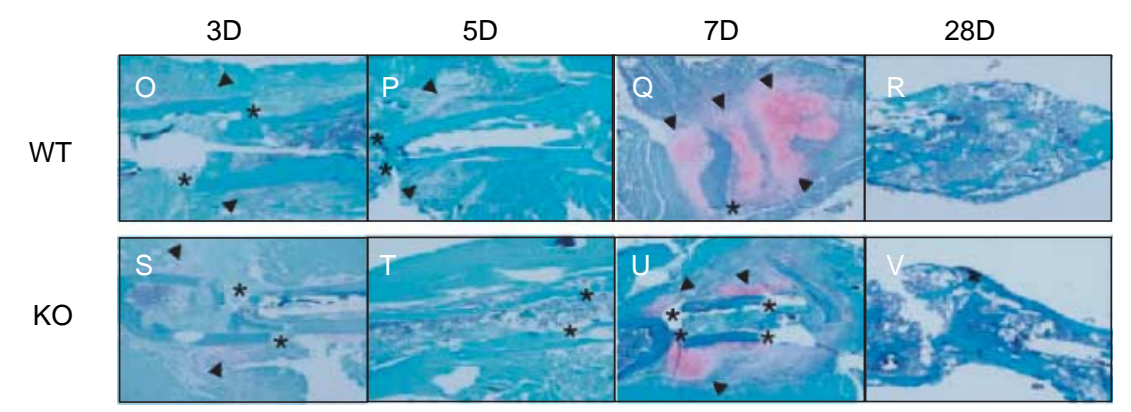

Figure 3 Histology of fractured femurs: Safranin O. Femoral sections from WT and PAPP-A KO mice were stained with Safranin O, which stains cartilage a pink-orange color. Asterisks denote the site of fracture. The immediate response involving the formation of the fracture hematoma (arrow head) is seen at 3 days post-fracture in both WT $(\mathrm{O})$ and PAPP-A KO (S). Chondrogenesis begins at 5 days in WT and at 7 days in PAPP-A KO mice (Pand $U$; arrows head), and is more pronounced in WT than in PAPP-A KO animals at 7 days (Q vs $U$, arrows head).

groups demonstrated an improvement in ultimate strength and a reduction in callus diameter between 28 and 42 days.

\section{Cellular mechanisms}

IGF-dependent IGFBP-4 protease activity is present in explants from post-fracture day 5 and day 12 calluses from WT mice (Fig. 4). In explants from the post-fracture day 5 calluses, there is also a degree of IGFBP-4 proteolysis, independent of exogenous IGF-II in the assay. This suggests that the levels of IGF being produced by the callus at this time point are increased, as previously reported (Okazaki et al. 2003, Wildemann et al. 2004) and consistent with the findings of IGF-independent IGFBP-4 proteolysis in bone cells (Durham et al. 1995). Interestingly, the amount of proteolysis appears to be reduced in the day 12 calluses compared with the day 5 calluses in WT mice. This suggests a reduction in the level of PAPP-A expressed at this time in the fracture healing process. There are no antibodies currently available that detect mouse PAPP-A, so this cannot be directly assessed at this time. In contrast to the robust proteolytic activity in calluses from WT mice, there was no IGFBP-4 proteolysis in callus explants from PAPP-A KO mice at either time point in the absence or presence of exogenous IGF.

The hypothesized mechanism for PAPP-A regulation of IGF action involves cleavage of the inhibitory IGFBP-4 protein thereby allowing an increase in local IGF to activate IGF-I receptors (Conover et al. 1995, Lawrence et al. 1999, Byun et al. 2001, Bunn \& Fowlkes 2003, Ortiz et al. 2003). To investigate this mechanism, the level of tyrosine phosphorylated IGF-I receptor, the first step in ligandmediated receptor activation, was determined in fresh callus lysates. In Fig. 5, the level of IGF-I receptor tyrosine phosphorylation is shown in the upper panel. Phosphorylated IGF-I receptor was evident at $97 \mathrm{kDa}$ in callus from WT mice at post-fracture day 5 , but there was no apparent tyrosine phosphorylation of the IGF-I receptor in callus from PAPP-A KO mice. MG-63 is an osteosarcoma cell line with abundant IGF-I receptors and is used as a positive control for phosphorylated receptor when stimulated with IGF-I. The total level of IGF-I receptor protein is demonstrated in the lower panel showing that IGF-I receptor was effectively immunoprecipitated in all samples. Quantitation of the phospho-bands from three separate pools

Table 1 Qualitative histology of fracture repair

\begin{tabular}{|c|c|c|c|c|c|c|c|c|c|}
\hline & Genotype & 3D & $5 \mathrm{D}$ & 7D & 10D & 14D & 21D & 28D & 42D \\
\hline \multicolumn{10}{|c|}{ Qualitative histology } \\
\hline \multirow[t]{2}{*}{ IM Bone } & $\mathrm{KO}$ & 0 & $0 \cdot 7$ & $1 \cdot 5$ & $2 \cdot 2$ & $3 \cdot 0$ & $0 \cdot 5$ & $1 \cdot 0$ & 0 \\
\hline & WT & 0 & $1 \cdot 8$ & $2 \cdot 4$ & $3 \cdot 2$ & $3 \cdot 9$ & 0 & $0 \cdot 3$ & 0 \\
\hline \multirow[t]{2}{*}{ Chondrogenesis } & $\mathrm{KO}$ & 0 & 0 & $2 \cdot 5$ & $3 \cdot 0$ & $2 \cdot 0$ & 0 & $0 \cdot 8$ & 0 \\
\hline & WT & 0 & $0 \cdot 5$ & $3 \cdot 2$ & $4 \cdot 4$ & $3 \cdot 7$ & 0 & 0 & 0 \\
\hline \multirow[t]{2}{*}{ Remodeling } & $\mathrm{KO}$ & 0 & 0 & 0 & 0 & $1 \cdot 0$ & $1 \cdot 2$ & $1 \cdot 4$ & $5 \cdot 0$ \\
\hline & WT & 0 & 0 & 0 & 0 & 0 & $3 \cdot 0$ & $2 \cdot 3$ & $5 \cdot 0$ \\
\hline
\end{tabular}

Scoring system: integer score (0-5) assigned to fracture sections from PAPP-A KO and WT mice for presence of feature, degree of feature relative to completion of phase and volume of feature. Mean value entered for each group. Intramembranous (IM) Bone: trabeculae forming in the periosteum at the fracture shoulder. Chondrogenesis: chondrocytes visible adjacent to intramembranous bone. Remodeling: trabecular bone, lacunae in the cortex and recanalization of the medullary portion of the bone adjacent to fracture site. 
Table 2 Mechanical testing

\begin{tabular}{|c|c|c|c|c|c|c|}
\hline & \multicolumn{3}{|l|}{28 Day } & \multicolumn{3}{|l|}{42 Day } \\
\hline & WT & $\mathrm{KO}$ & $P$ value & WT & $\mathrm{KO}$ & $P$ value \\
\hline \multicolumn{7}{|l|}{ Fractured femur } \\
\hline Force to failure $^{a}$ & $33 \cdot 21$ & $22 \cdot 14$ & $0 \cdot 0336$ & $30 \cdot 311$ & $18 \cdot 977$ & $0 \cdot 0174$ \\
\hline Ultimate strength $^{\mathrm{b}}$ & $5 \cdot 108$ & $5 \cdot 826$ & $0 \cdot 3348$ & $8 \cdot 369$ & $9 \cdot 29$ & $0 \cdot 3988$ \\
\hline Diameter ${ }^{c}$ & $2 \cdot 898$ & $2 \cdot 216$ & $0 \cdot 0002$ & $2 \cdot 127$ & $1 \cdot 589$ & $0 \cdot 0001$ \\
\hline \multicolumn{7}{|c|}{ Percent of unfractured femur } \\
\hline Force to failure ${ }^{a}$ & $0 \cdot 813$ & $0 \cdot 799$ & $0 \cdot 9097$ & $0 \cdot 779$ & $0 \cdot 776$ & 0.9849 \\
\hline Ultimate strength $^{\mathrm{b}}$ & $0 \cdot 237$ & $0 \cdot 312$ & $0 \cdot 1896$ & $0 \cdot 402$ & $0 \cdot 434$ & $0 \cdot 4342$ \\
\hline Diameter ${ }^{\mathrm{C}}$ & $1 \cdot 89$ & $1 \cdot 709$ & $0 \cdot 2461$ & $1 \cdot 387$ & $1 \cdot 288$ & $0 \cdot 068$ \\
\hline
\end{tabular}

Femurs underwent mechanical testing using the torsion test, as described in Materials and Methods.

${ }^{\mathrm{a}}$ Force to failure, $\mathrm{N}-\mathrm{mm}$.

${ }^{\mathrm{b}}$ Ultimate strength, $\mathrm{N} / \mathrm{mm}^{2}$

${ }^{\mathrm{c}}$ Femur diameter, $\mathrm{mm}$.

of calluses indicated a three fold difference in arbitrary scanning units in WT compared with PAPP-A KO groups $(0 \cdot 68 \pm 0 \cdot 052$ vs $0 \cdot 22 \pm 0 \cdot 035, P=0 \cdot 0008)$.

\section{Discussion}

The results of this study establish an important role for PAPP-A in the normal fracture healing process. Thus, we have shown by radiographic and histologic methods that fracture healing in the absence of PAPP-A is strikingly delayed. We have also shown that PAPP-A, measured as IGFBP-4 protease activity, is expressed in the fracture callus of WT mice and appears to be increased in the early phases of fracture healing. There was no IGFBP-4 protease activity in calluses of PAPP-A KO mice. This is further evidence that PAPP-A is the principle, and perhaps the only physiological IGFBP-4 protease. Callus explants from PAPP-A KO mice also appeared to have decreased IGF-I receptor activation, as assessed by the tyrosine phosphorylation state of the receptor. Overall, our findings fit with the emerging concept of PAPP-A, not as an essential

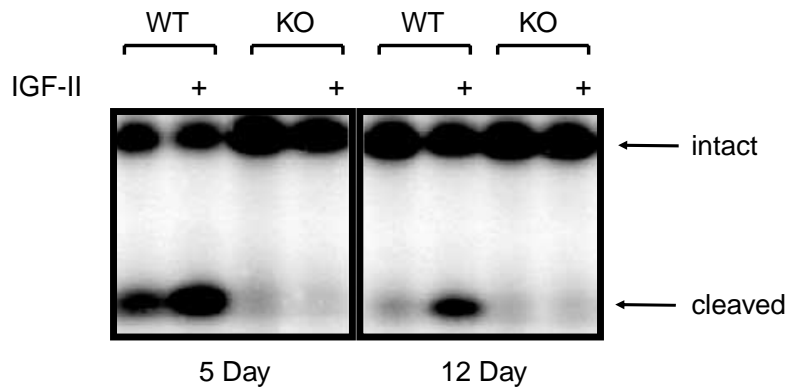

Figure 4 IGFBP-4 protease activity in fracture callus. Calluses 5 and 12 days post-fracture were isolated from WT and PAPP-A KO mice and cultured in serum-free medium for $48 \mathrm{~h}$. The conditioned medium was then incubated with $\left[{ }^{125}\right.$ I]IGFBP-4 without or with $(+)$ IGF-II for $6 \mathrm{~h}$. Reaction products were visualized by autoradiography. Arrows indicate intact and cleaved IGFBP-4. growth factor itself, but as an acute positive modulator of local IGF action.

Initial characterization of the PAPP-A KO mouse phenotype indicated proportional dwarfism and a slight delay in bone mineralization (Conover et al. 2003). This appeared to be due to the absence of IGFBP-4 proteolytic activity and consequent limitation of fetal IGF-II bioavailability during a critical time early in embryogenesis. Both the dwarf phenotype and the delayed skeletal mineralization could be rescued by increasing IGF-II expression during fetal development (Bale \& Conover 2005). At this point, we do not know whether PAPP-A is regulating IGF-I or IGF-II (or both) during fracture repair. We propose that it is IGF-I based on the fact that IGF-I is known to be expressed in the rodent fracture model (Wang et al. 1995, Okazaki et al. 2003, Shimoaka et al. 2004, Wildemann et al. 2004) and IGF-I is the predominant IGF expressed by rodent bone cells (Conover \& Rosen 2002). However, IGF-II message can be found in the rodent growth plate, perhaps recapitulating skeletal growth in the fetal and neonatal periods (Shinar et al. 1993). In situ hybridization studies are in progress to address this issue. Nonetheless, both IGF-I and IGF-II signal through IGF-I receptors that are widely distributed on the different cell types

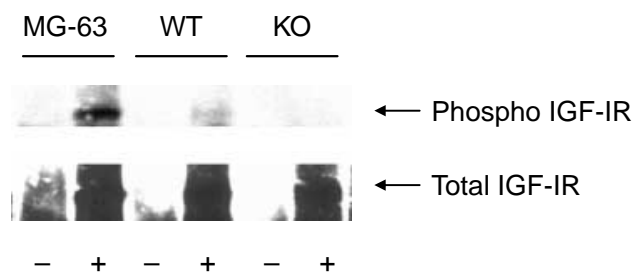

Figure 5 Tyrosine phosphorylation of IGF-I receptor in fracture callus. Calluses 5 days post-fracture were isolated from WT and PAPP-A KO mice and rapidly lysed and immunoprecipitated with antibody to IGF-I receptor $(+)$ or nonspecific $\operatorname{lgG}(-)$ as described in Materials and Methods. Immunoprecipitates were resolved on SDS-PAGE and immunoblotted with phosphotyrosine antibody (upper panel) or IGF-I receptor antibody (lower panel). MG-63 osteosarcoma cells treated with IGF-I for 10 min were used as a positive control. 
in the fracture and throughout the fracture repair process (Wang et al. 1995). The importance of the IGF signaling pathway in fracture healing has recently been supported by the absence of callus formation in mice deficient in a major intracellular mediator of IGF-I receptor signal transduction, insulin receptor substrate-1 (IRS-1; Shimoaka et al. 2004). The greater severity of fracture impairment in IRS-1 KO mice than in PAPP-A KO mice may reflect the differing roles of these proteins, i.e. IRS-1 as a key intermediate in the IGF receptor signaling pathway and PAPP-A as a modifier of IGF action. Although the most likely mechanism for the observed delay in fracture repair in PAPP-A $\mathrm{KO}$ mice involves the documented loss of IGFBP-4 proteolytic activity, other IGFBP substrates or other as yet unknown functions of PAPP-A could also contribute to these results (Laursen et al. 2001).

Our data suggest that the IGFBP-4 proteolytic activity of PAPP-A is operative during the fracture healing process in WT mice and appears to be higher in the earlier phases of fracture healing (day 5 compared to day 12). Day 5 represents intramembranous ossification overlapping with endochondral ossification. The latter continues until the soft callus is completely replaced by bone and this new bone bridges the fracture gap. These stages involve proliferation of chondrocytes and cells of the osteoblast lineage, and IGFs are important regulators of both cell types (Vetter et al. 1986, McCarthy et al. 1989, Wergedal et al. 1990, Conover \& Rosen 2002). In vitro data have shown that PAPP-A protein and IGFBP-4 proteolytic activity are present in media conditioned by human osteoblasts and rabbit periosteal chondrocytes (AuwYang et al. 2003, Ortiz et al. 2003). In addition, PAPP-A mRNA is expressed in cartilaginous tissue of the rib cage and intramembranous bone of the calvaria, as well as in the femur and tibia of WT mice (Conover et al. 2003). Another cell type that may play a role in fracture repair is the bone marrow stromal cell. IGF-I stimulates proliferation of bone marrow stromal cells (Thomas et al. 1999), and PAPP-A is highly expressed in human marrow stromal cells (Lawrence et al. 1999). Further study is required to determine the particular stage of the fracture healing process and the particular cell type that is regulated by PAPP-A. Since the ultimate result of the fracture healing process is normal in PAPP-A KO mice, we propose that PAPP-A is important in the early release of bioavailable IGF in the callus environment. In addition, PAPP-A may also have IGF-independent functions on bone cell differentiation (Jadlowiec et al. 2005).

Remodeling of the fracture serves to restore the normal structure of the bone and biomechanical competency. At the later histological time points in this study, the fracture appears to be remodeled comparatively in the PAPP-A KO and WT mice. Moreover, mechanical testing data did not reveal any significant differences in bone component strength in the healed fractures between WT and PAPP-A KO mice. Based on the delay seen by histologic and radiographic analyses, it is probable that mechanical testing earlier in the healing process would reveal differences in bone strength. Nevertheless, it appears that PAPP-A functions primarily to accelerate the healing of skeletal defects that would heal spontaneously. Similar conclusions were drawn from the effects of IGF-I and transforming growth factor (TGF)- $\beta$ on the fracture repair process, i.e. that local growth factors primarily affect the rate of fracture repair (Schmidmaier et al. 2002, Longobardi et al. 2006). It may be relevant in this regard that TGF- $\beta$ is the most potent stimulator of $P A P P-A$ gene expression in human osteoblasts (Ortiz et al. 2003, Conover et al. 2004). Preliminary data suggest that TGF- $\beta$ treatment increases PAPP-A expression during periosteal chondrogenesis (AuwYang et al. 2003). In addition, pro-inflammatory cytokines that are expressed in the fracture callus (Einhorn et al. 1995, Kon et al. 2001) also increase PAPP-A expression in bone cells (Kon et al. 2001).

Our studies are the first to document a role for PAPP-A in fracture repair. Further studies will help elucidate the mechanisms through which PAPP-A and other components of the IGF system, as well as other local factors, regulate the fracture healing process. This information is likely to lead to new therapeutic approaches to accelerate skeletal healing.

\section{Funding}

This work was supported by the Mayo Foundation. The authors declare that there is no conflict of interest that would prejudice the impartiality of this scientific work.

\section{References}

Andrew JG, Hoyland J, Freemont AJ \& Marsh D 1993 Insulinlike growth factor gene expression in human fracture callus. Calcified Tissue International 53 97-102.

AuwYang KG, Schwab J, Clemens V, Conover CA, Saris DBF \& O'Driscoll SW 2003 The influence of TGF- $\beta$ on the mRNA levels of IGFBP-4 and PAPP-A during periosteal chondrogenesis. Transactions in Orthopaedic Reserarch Society 28622.

Bale LK \& Conover CA 2005 Disruption of insulin-like growth factor-II imprinting during embryonic development rescues the dwarf phenotype of mice null for pregnancy-associated plasma protein-A. Journal of Endocrinology 186 325-331.

Bayes-Genis A, Schwartz RS, Lewis DA, Overgaard MT, Christiansen M, Oxvig C, Ashai K, Holmes DR Jr \& Conover CA 2001 Insulin-like growth factor binding protein-4 protease produced by smooth muscle cells increases in the coronary artery after angioplasty. Arteriosclerosis, Thrombosis, and Vascular Biology 21 335-341.

Boldt HB, Overgaard MT, Laursen LS, Weyer K, Sottrup-Jensen L \& Oxvig C 2001 Mutational analysis of the proteolytic domain of pregnancy-associated plasma protein-A (PPAP-A): classification as a metzincin. Biochemical Journal 358 359-367.

Bonnarens F \& Einhorn TA 1984 Production of a standard closed fracture in laboratory animal bone. Journal of Orthopaedic Research 2 97-101.

Bunn RC \& Fowlkes JL 2003 Insulin-like growth factor binding protein proteolysis. Trends in Endocrinology and Metabolism 14 176-181.

Byun D, Mohan S, Yoo M, Sexton C, Baylink DJ \& Qin X 2001 Pregnancyassociated plasma protein-A accounts for the insulin-like growth factor (IGF)-binding protein-4 (IGFBP-4) proteolytic activity in human pregnancy serum and enhances the mitogenic activity of IGF by degrading IGFBP-4 in vitro. Journal of Clinical Endocrinology and Metabolism 86 847-854. 
Chen B-K, Leiferman KM, Pittelkow MR, Overgaard MT, Oxvig C \& Conover CA 2003 Localization and regulation of pregnancy-associated plasma protein A expression in healing human skin. Journal of Clinical Endocrinology and Metabolism 88 4465-4471.

Conover CA \& Rosen C 2002 The role of insulin-like growth factors and binding proteins in bone cell biology. In Principles of Bone Biology, 2nd edn, ch 45, pp 801-815. Eds JP Bilezikian, LG Raisz \& GA Rodan. San Diego, CA: Academic Press.

Conover CA, Durham SK, Zapf J, Masiarz FR \& Kiefer MC 1995 Cleavage analysis of insulin-like growth factor (IGF)-dependent IGF-binding protein-4 proteolysis and expression of protease-resistant IGF-binding protein-4 mutants. Journal of Biological Chemistry $\mathbf{2 7 0}$ 4395-4400.

Conover CA, Lee PDK, Riggs BL \& Powell DR 1996 Insulin-like growth factor-binding protein-1 expression in cultured human bone cells: regulation by insulin and glucocorticoid. Endocrinology 137 3295-3301.

Conover CA, Bale LK, Overgaard MT, Johnstone EW, Laursen UH, Fuchtbauer E-M, Oxvig C \& van Deursen J 2003 Metalloproteinase pregnancy-associated plasma protein $\mathrm{A}$ is a critical growth regulatory factor during fetal development. Development 131 1187-1194.

Conover CA, Chen B-K \& Resch ZT 2004 Regulation of pregnancyassociated plasma protein-A expression in cultured human osteoblasts. Bone 34 297-302.

Duan C \& Xu Q 2005 Roles of insulin-like growth factor (IGF) binding proteins in regulating IGF actions. General and Comparative Endocrinology 142 44-52.

Durham SK, De Leon DD, Okazaki R, Riggs BL \& Conover CA 1995 Regulation of insulin-like growth factor (IGF)-binding protein-4 availability in normal human osteoblast-like cells: role of endogenous IGFs. Journal of Clinical Endocrinology and Metabolism 80 104-110.

Einhorn TA, Majeska RJ, Rush EB, Levine PM \& Horowitz MC 1995 The expression of cytokine activity by fracture callus. Journal of Bone and Mineral Research 10 1272-1281.

Ferguson C, Alpern E, Miclau T \& Helms JA 1999 Does adult fracture repair recapitulate embryonic skeletal formation? Mechanisms of Development $\mathbf{8 7}$ $57-66$.

Gerstenfeld LC, Cullinane DM, Barnes GL, Graves DT \& Einhorn TA 2003 Fracture healing as a post-natal developmental process: molecular, spatial, and temporal aspects of its regulation. Journal of Cellular Biochemistry $\mathbf{8 8}$ 783-784.

Hassager C, Fitzpatrick LA, Spencer EM, Riggs BL \& Conover CA 1992 Basal and regulated secretion of insulin-like growth factor binding proteins in osteoblast-like cells is cell line specific. Journal of Clinical Endocrinology and Metabolism 75 228-233.

Higdon A, Ohlsen EH, Stiles WB, Weese JA \& Riley WF 1985 Mechanics of Materials. 4th edn, New York, NY: John Wiley \& Sons, Inc.

Jadlowiec J, Dongell D, Smith J, Conover C \& Campbell P 2005 Pregnancyassociated plasma protein-A is involved in matrix mineralization of human adult mesenchymal stem cells and angiogenesis in the chick chorioallontoic membrane. Endocrinology 146 3765-3772.

Jingushi S, Joyce ME \& Bolander ME 1992 Genetic expression of extracellular matrix proteins correlates with histologic changes during fracture repair. Journal of Bone and Mineral Research 7 1045-1055.

Joyce ME, Jingushi S \& Bolander ME 1990a Transforming growth factor- $\beta$ in the regulation of fracture repair. Orthopedic clinics of North America 21 199-209.

Joyce ME, Roberts AB, Sporn MB \& Bolander ME $1990 b$ Transforming growth factor- $\beta$ and the initiation of chondrogenesis and osteogenesis in the rat femur. Journal of Cell Biology 110 2195-2207.

Kon T, Cho T-J, Aizawa T, Yamazaki M, Nooh N, Graves D, Gerstenfeld LC \& Einhorn TA 2001 Expression of osteoprotegerin, receptor activator of $\mathrm{NF}-\mathrm{\kappa B}$ ligand (osteoprotegerin ligand) and related proinflammatory cytokines during fracture healing. Journal of Bone and Mineral Research 16 1004-1014.

LaTour D, Mohan S, Linkhart TA, Baylink DJ \& Strong DD 1990 Inhibitory insulin-like growth factor-binding protein: cloning, complete sequence, and physiological regulation. Molecular Endocrinology 4 1806-1814.
Laursen LS, Overgaard MT, Soe R, Boldt HB, Sottrup-Jensen L, Giudice LC, Conover CA \& Oxvig C 2001 Pregnancy-associated plasma protein-A (PAPP-A) cleaves insulin-like growth factor binding protein (IGFBP)-5 independent of IGF: implications for the mechanism of IGFBP-4 proteolysis by PAPP-A. FEBS Letters $\mathbf{5 0 4} 3640$.

Lawrence JB, Oxvig C, Overgaard MT, Sottrup-Jensen L, Gleich GJ, Hays LG, Yates JR III \& Conover CA 1999 The insulin-like growth factor (IGF)dependent IGF binding protein-4 protease secreted by human fibroblasts is pregnancy associated plasma protein-A. PNAS 96 3149-3153.

Le Roith D, Bondy C, Yakar S, Liu J-L \& Butler A 2001 The somatomedin hypothesis: 2001. Endocrine Reviews 22 53-74.

Longobardi L, O’Rear L, Aakula S, Johnstone B, Shimer K, Chytil A, Horton WA, Moses HL \& Spagnoli A 2006 Effect of IGF-I in the chondrogenesis of bone marrow mesenchymal stem cells in the presence or absence of TGF- $\beta$ signaling. Journal of Bone and Mineral Research 21 626-636.

Lotinun S, Evans GL, Bronk JT, Bolander ME, Wronski TJ, Ritman EL \& Turner RT 2004 Continuous parathyroid hormone induces cortical porosity in the rat: effects on bone turnover and mechanical properties. Journal of Bone and Mineral Research 19 1165-1171.

McCarthy TL, Centrella M \& Canalis E 1989 Regulatory effects of insulinlike growth factors I and II on bone collagen synthesis in rat calvarial cultures. Endocrinology 124 301-309.

Miyakoshi N, Qin X, Kasukawa Y, Richman C, Srivastava AK, Baylink DJ \& Mohan S 2006 Systemic administration of insulin-like growth factor (IGF)binding protein-4 (IGFBP-4) increases bone formation parameters in mice by increasing IGF bioavailability via an IGFBP-4 protease-dependent mechanism. Endocrinology 142 2641-2648.

Okazaki K, Jingushi S, Ikenoue T, Urabe K, Sakai H \& Iwamoto Y 2003 Expression of parathyroid hormone-related peptide and insulin-like growth factor I during rat fracture healing. Journal of Orthopaedic Research 21 $511-520$.

Ortiz C, Chen B-K, Bale LK, Overgaard MT, Oxvig C \& Conover CA 2003 Transforming growth factor- $\beta$ regulation of the insulin-like growth factor binding protein-4 protease system in cultured human osteoblasts. Journal of Bone and Mineral Research 18 1066-1072.

Overgaard MT, Haaning J, Boldt HB, Olsen IM, Laursen LS, Christiansen M, Gleich GJ, Sottrup-Jensen L, Conover CA \& Oxvig C 2000 Expression of recombinant human pregnancy-associated plasma protein-A and identification of the proform of eosinophil major basic protein as its physiological inhibitor. Journal of Biological Chemistry 275 31128-31133.

Qin X, Byun D, Strong DD, Baylink DJ \& Mohan S 1999 Studies on the role of human insulin-like growth factor-II (IGF-II)-dependent IGF binding protein (hIGFBP)-4 protease in human osteoblasts using protease-resistant IGFBP-4 analogs. Journal of Bone and Mineral Research 14 2079-2088.

Qin X, Byun D, Lau K-H, Baylink DJ \& Mohan S 2000 Evidence that the interaction between insulin-like growth factor (IGF)-II and IGF binding protein (IGFBP)-4 is essential for the action of the IGF-II-dependent IGFBP-4 protease. Archives of Biochemistry and Biophysics 327 209-216.

Rechler MM \& Clemmons DR 1998 Regulatory actions of insulin-like growth factor-binding proteins. Trends in Endocrinology and Metabolism 9 176-183.

Resch ZT, Simari RD \& Conover CA 2006 Targeted disruption of the pregnancy-associated plasma protein-A gene is associated with diminished smooth muscle cell response to insulin-like growth factor-I and resistance to neointimal hyperplasia after vascular injury. Endocrinology 147 5634-5640.

Schmidmaier G, Wildemann B, Heeger J, Gabelein T, Flyvbjerg A, Bail HJ \& Raschke M 2002 Improvement of fracture healing by systemic administration of growth hormone and local application of insulin-like growth factor- 1 and transforming growth factor- $\beta 1$. Bone 31 165-172.

Shimoaka T, Kamekura S, Chikuda H, Hoshi K, Chung U-i, Akune T, Maruyama Z, Komori T, Matsumoto M, Ogawa W et al. 2004 Impairment of bone healing by insulin receptor substrate-1 deficiency. Journal of Biological Chemistry 279 15314-15322. 
Shinar DM, Endo N, Halperin D, Rodan GA \& Weinreb M 1993 Differential expression of insulin-like growth factor-I (IGF-I) and IGFII messenger ribonucleic acid in growing rat bone. Endocrinology 132 1158-1167.

Thomas T, Gori F, Spelsberg TC, Khosla S, Riggs BL \& Conover CA 1999 Response of bipotential human marrow stromal cells to insulin-like growth factors: effect on binding protein production, proliferation, and commitment to osteoblasts and adipocytes. Endorinology 140 5036-5044.

Trippel SB 1998 Potential role of insulinlike growth factors in fracture healing. Clinical Orthopaedics and Related Research 355S S301-S313.

Vetter U, Zapf J, Heit W, Helbing G, Heinze E, Froesch ER \& Taller WM 1986 Human fetal and adult chondrocytes: effect of insulinlike growth factors I and II, insulin, and growth hormone on clonal growth. Journal of Clinical Investigation 77 1903-1908.

Wang E, Wang J, Chin E, Zhou J \& Bondy CA 1995 Cellular patterns of insulin-like growth factor system gene expression in murine chondrogenesis and osteogenesis. Endocrinology 136 2741-2751.
Wergedal JE, Mohan S, Lundy M \& Baylink DJ 1990 Skeletal growth factor and other growth factors known to be present in bone matrix stimulate proliferation and protein synthesis in human bone cells. Journal of Bone and Mineral Research 5 179-186.

Wildemann B, Schmidmaier G, Brenner N, Huning M, Stange R, Haas NP \& Raschke M 2004 Quantitation, localization, and expression of IGF-I and TGF- $\beta 1$ during growth factor-stimulated frature healing. Calcified Tissue International 74 388-397.

Zhang M, Faugere M-C, Malluche H, Rosen CJ, Chernausek SD \& Clemens TL 2003 Paracrine overexpression of IGFBP-4 in osteoblasts of transgenic mice decreases bone turnover and causes global growth retardation. Journal of Bone and Mineral Research 18 836-843.

Received in final form 14 December 2006

Accepted 21 December 2006

Made available online as an Accepted Preprint

28 December 2006 